\title{
Mycorrhizal Fungi Regulate Root Responses and Leaf Physiological Activities in Trifoliate Orange
}

\author{
Chun-Yan LIU ${ }^{1,2}$, A.K. SRIVASTAVA³, Qiang-Sheng WU ${ }^{1,2,4 *}$ \\ ${ }^{1}$ Yangtze University, College of Horticulture and Gardening, Jingzhou, Hubei 434025, \\ China; chunyanliu_2009@126.com;wuqiangsh@163.com ("correspondingauthor) \\ ${ }^{2}$ Yangtze University, Institute of Root Biology, Jingzhou, Hubei 434025, China \\ ${ }^{3}$ ICAR-Central Citrus Research Institute, Nagpur 440033, Maharashtra, India; aksrivas2007@gmail.com \\ ${ }^{4}$ University of Hradec Kralove, Faculty of Science, Department of Chemistry, Hradec Kralove, Czech Republic
}

\begin{abstract}
Plant responses to mycorrhization are mediated through secretion of certain signal molecules deposited in mycorrhizosphere in response to environmental stimuli. Responses of four arbuscular mycorrhizal fungi (AMF), namely Claroideoglomus etunicatum, Diversispora versiformis, Funneliformis mosseae, and Rhizoglomus intraradices on root morphology, lateral root (LR) number, and leaf carbohydrates, nitric oxide (NO), and calmodulin (CaM) changes were studied using trifoliate orange. Inoculation response of D. versiformis, F. mosseae, and R. intraradices registered significantly higher plant growth performance (plant height, stem diameter, leaf number, and shoot and root biomass), root morphological traits (total length, projected area, surface area, and volume), and LR number (first-, second-, third-, and forth-order), compared to un-inoculated response. Higher concentrations of $\mathrm{CaM}, \mathrm{NO}$, glucose, and fructose and lower sucrose level in leaves were observed in AMF-seedlings than in non-AMF seedlings. Correlation studies further revealed, root morphological traits and LR numbers were significantly negatively correlated with sucrose whereas positively correlated with glucose, fructose, $\mathrm{NO}$, and CaM level in leaves. These results suggested, AMF-induced root modification is routed through sucrose cleavage and partly through changes in $\mathrm{NO}$ and $\mathrm{CaM}$.
\end{abstract}

Keywords: calmodulin, nitric oxide, root morphology, symbiosis, sucrose cleavage

\section{Introduction}

Arbuscular mycorrhizal fungi (AMF) are reported to establish symbiotic association, with roots of $\sim 80 \%$ of terrestrial plants (Kiers and van der Heijden, 2006). Such symbiosis derives $\sim 20 \%$ of photosynthetic carbohydrates from the host plant on account for mycorrhizal growth, and in return, AMF provide the host plant, a greater access to nutrients and water absorption (Smith and Read, 2008; Parniske, 2008). The essential roles of AMF in crops like citrus, litchi, strawberry, lettuce, pepper etc are well documented (Borowicz, 2010; Ortas et al., 2011). Trifoliate orange [Poncirus trifoliata (L.) Raf.] is a rootstock used in citriculture in Asia (Srivastava et al., 2008). Citrus is usually considered as a crop severely lacking in root hair (Srivastava and Singh, 2009; Wu et al., 2016), and thus depends heavily on AMF for meeting the nutrient requirement.

Root systems play a significant role in acquisition of nutrients from within a given soil volume (Yao et al., 2009). Different microbial communities play an important role in growth and developmental responses in host plants (Sorgona $e t$ al., 2007; Jung et al., 2013). Of them, AMF have shown to regulate root system architecture through enhanced mineral nutrient absorption (Smith and Read, 2008). Earlier studies showed that AMF-inoculation strong stimulated morphological modification in root features like root length, surface area, and volume to varying proportions (Schellenbaum et al., 1991; Wu et al., 2011, 2015a). AMF-induced root modification is reported to have strong relations with metabolism of endogenous polyamines (Wu et al., 2010). However, such relationship is independent of signaling of common symbiotic transactions (Gutjahr et al., 2009). On the other hand, Isobe $e t$ al. (2002) reported a negative effect of AMF inoculation on the length and the number of tap roots and lateral roots (LRs) in Phaseolus vulgaris. Root morphological alteration depends on AMF species and plant genotypes (Yao et al., 2009; Wu et al., 2011; Li et al., 2013). These studies suggested number of mechanisms involved in describing AMF-induced LR development such as, excretion of AMF spore germination, phosphorus (P) nutrition 
improvement, changes in hormone levels, sugar signals, synthesis of nitric oxide (NO) as a signaling molecule, and active involvement of calmodulin (CaM) as $\mathrm{Ca}^{2+}$ receptors (Zhao et al., 2007; Yang et al., 2010; Chen and Kao, 2012; Zhang et al., 2013; Fusconi, 2014).

In this background, the present study evaluated the responses of different AMF species on root colonization, root morphology, LR number, and leaf carbohydrates, NO, and $\mathrm{CaM}$ changes to understand the underlying mechanistic insights involved.

\section{Materials and Methods}

\section{Experimentalsetup}

The experiment was carried out during March-August, 2013 at Yangtze University, Jingzhou, China. On March 30, 2013, five-leaf-old seedlings ( $\sim 6 \mathrm{~cm}$ height) without mycorrhization were transplanted into a 4.8 -L pot filled with $4.5 \mathrm{~kg}$ autoclaved $\left(121{ }^{\circ} \mathrm{C}\right.$, 2h) sands. As many four AMF species viz., Claroideoglomus etunicatum (W.N. Becker \& Gerd.) C. Walker \& A. Schüßler, Diversispora versiformis (P. Karst.) Oehl, G.A. Silva \& Sieverd, Funneliformis mosseae (T.H. Nicolson \& Gerd.) C. Walker \& A. Schüßler, and Rhizoglomus intraradices (N.C. Schenck \& G.S. Sm.) C. Walker \& A. Schüßler were tested. As a result, the experiment had five treatments, namely, $C$. etunicatum, D. versiformis, $F$. mosseae, $R$. intraradices and nonAMF control. Each treatment had four replicates, for a total of 20 pots (three seedlings per pot).

At the same time, approx. 1000 spores of each AM fungus used were mixed along with sands for AMF treatment. The nonAMF control received the same amount of autoclaved inoculums plus $2 \mathrm{~mL}$ filtrate $(25 \mu \mathrm{m}$ filter $)$ of mycorrhizal inoculums to minimize the differences in other microbial communities. Seedlings were grown in a controlled environment characterized by $27 / 20{ }^{\circ} \mathrm{C}$ (day/night) temperature, 982 $\mu \mathrm{mol} / \mathrm{m}^{2} / \mathrm{s}$ photonflux density, and $80 \%$ relative air humidity. A $150 \mathrm{~mL}$ Hoagland solution (1/10 P strength) was applied into each pot at an alternate day. The AMF- and non-AMF seedlings were harvested on August 17, 2013.

\section{Observations and analysis}

Plants following their harvest, were divided into shoots and roots, and recorded the fresh biomass. The root system from each pot was scanned with the Epson Perfection V700 Photo Dual Lens System (Seiko Epson Corp, Japan). Root images were then analyzed through the WinRHIZO software (Regent Instruments Incorporated, Canada), to obtain different root traits viz., length, surface area, volume, and diameter. The root of seedlings was divided into taproot and LRs, to count the number of LRs artificially on a test-bed.
Root mycorrhizal colonization was determined using clearing with $10 \% \mathrm{KOH}$ at $90{ }^{\circ} \mathrm{C}$ for $1.5 \mathrm{~h}$, then staining with $0.05 \%$ trypan blue for $5 \mathrm{~min}$ (Phillips and Hayman, 1970).

NO concentration in leaves was estimated with the ELISA assay with NO kit (A012, Nanjing Jiancheng Bioengineering Institute, Nanjing, China) and CaM using the Plant CaM ELISA Kit (YAD 001, Beijing Dingguochangsheng Biotechnology Co. Ltd., Beijing, China). Carbohydrate forms such as fructose, glucose and sucrose concentrations in leaves were assayed through the protocol as described by Wu et al. (2015b).

\section{Statistical analysis}

Data (means $\pm \mathrm{SD}, n=4$ ) were analyzed by one-way variance (ANOVA). Significant differences between treatments were compared with the Duncan's multiple range tests at $P<0.05$. Pearson correlation coefficients between variables were carried out with Proc Corr procedure. All the statistical analyses were performed using the SAS software 8.1v.

\section{Results and Discussion}

Root mycorrbizal colonization and plant growth performance

Mycorrhizal colonization is associated with different plant growth parameters through an increase in root absorptive surface area (Aguín et al., 2004). Root AMF colonization was observed to vary from $17.64 \%$ to $29.69 \%$, following the order of $F$. mosseae $\approx D$. versiformis $>R$. intraradices $>C$. etunicatum in the decreasing order (Table 1). With the exception of C. etunicatum, other three AMF species showed a significant increase in different growth attributing parameters viz., plant height, stem diameter, leaf number, and shoot and root biomass, compared to non-AMF treatment (Table 1). Studies in the past showed strong positive effect of AMF colonization on growth of the host plant (Aguín et al., 2004). Our studies showed, except $C$. etunicatum, inoculation with $F$. mosseae, $D$. versiformis, and $R$. intraradices produced significantly better plant growth performance, which is possible due to improved nutrients and the compatibility between AMF and host plants (Yao et al., 2009).

\section{Response on root traits}

AMF-inoculation was observed to alter different root traits of trifoliate orange seedlings (Fig. 1; Table 2). Out of four AMF species, three species viz., $F$. mosseae, $D$. versiformis and $R$. intraradices significantly increased root total length, projected area, surface area, and volume; however, $C$. etunicatum increased root total length only. Root average diameter also, remained unaffected with all the four AMF species. Likewise higher LR number was recorded in different order than non-AMF-

Table 1. Effects of different AMF species (Claroideoglomus etunicatum, Diversispora versiformis, Funneliformis mosseae, and Rhizoglomus intraradices) on plant growth and mycorrhizal development of trifoliate orange (Poncirus trifoliata) seedlings

\begin{tabular}{lccccc}
\hline \multicolumn{1}{c}{ Treatments } & $\begin{array}{c}\text { Plant height } \\
(\mathrm{cm})\end{array}$ & $\begin{array}{c}\text { Stem diameter } \\
(\mathrm{mm})\end{array}$ & Leaf number & \multicolumn{2}{c}{$\begin{array}{c}\text { BMF colonization } \\
(\%)\end{array}$} \\
\hline Non-AMF & $36.6 \pm 3.6 \mathrm{c}$ & $3.57 \pm 0.29 \mathrm{c}$ & $32 \pm 2 \mathrm{~b}$ & $2.69 \pm 0.34 \mathrm{c}$ & $1.83 \pm 0.35 \mathrm{~d}$ \\
C. etunicatum & $36.1 \pm 6.7 \mathrm{c}$ & $3.55 \pm 0.16 \mathrm{c}$ & $32 \pm 3 \mathrm{~b}$ & $2.64 \pm 0.68 \mathrm{c}$ & $1.72 \pm 0.35 \mathrm{~d}$ \\
D. versiformis & $66.5 \pm 3.2 \mathrm{a}$ & $4.79 \pm 0.39 \mathrm{a}$ & $41 \pm 2 \mathrm{a}$ & $7.06 \pm 0.51 \mathrm{a}$ & $3.86 \pm 0.31 \mathrm{~b}$ \\
F. mosseae & $67.6 \pm 7.5 \mathrm{a}$ & $5.08 \pm 0.40 \mathrm{a}$ & $43 \pm 2 \mathrm{a}$ & $7.60 \pm 0.93 \mathrm{a}$ & $29.58 \pm 1.36 \mathrm{a}$ \\
R. intraradices & $56.5 \pm 6.0 \mathrm{~b}$ & $4.37 \pm 0.33 \mathrm{~b}$ & $40 \pm 3 \mathrm{a}$ & $5.11 \pm 0.94 \mathrm{~b}$ & $2.83 \pm 0.45 \mathrm{c}$ \\
\hline
\end{tabular}

Note: Data (means \pm SD, $n=4)$ followed by different letters indicate significant differences $(P<0.05)$ between treatments 
Table 2. Effects of different AMF species (Claroideoglomus etunicatum, Diversispora versiformis, Funneliformis mosseae, and Rhizoglomus intraradices) on root morphological traits and lateral root (LR) number of trifoliate orange (Poncirus trifoliata) seedlings

\begin{tabular}{|c|c|c|c|c|c|c|c|c|c|}
\hline \multirow[b]{2}{*}{ Treatments } & \multirow{2}{*}{$\begin{array}{l}\text { Total } \\
\text { length } \\
(\mathrm{cm})\end{array}$} & \multirow{2}{*}{$\begin{array}{c}\text { Project } \\
\text { area } \\
\left(\mathrm{cm}^{2}\right)\end{array}$} & \multirow[b]{2}{*}{$\begin{array}{l}\text { Surface area } \\
\qquad\left(\mathrm{cm}^{2}\right)\end{array}$} & \multirow{2}{*}{$\begin{array}{c}\text { Average } \\
\text { diameter } \\
(\mathrm{mm})\end{array}$} & \multirow[b]{2}{*}{$\begin{array}{l}\text { Volume } \\
\left(\mathrm{cm}^{3}\right)\end{array}$} & \multicolumn{4}{|c|}{ Number of LR (\#/plant) } \\
\hline & & & & & & $\begin{array}{l}\text { First- } \\
\text { order }\end{array}$ & $\begin{array}{c}\text { Second- } \\
\text { order }\end{array}$ & $\begin{array}{l}\text { Third- } \\
\text { order }\end{array}$ & $\begin{array}{l}\text { Forth- } \\
\text { order }\end{array}$ \\
\hline Non-AMF & $373 \pm 16 \mathrm{e}$ & $58.4 \pm 7.4 \mathrm{~b}$ & $183.4 \pm 5.6 b$ & $1.50 \pm 0.24 \mathrm{a}$ & $6.57 \pm 0.86 \mathrm{~b}$ & $49 \pm 3 c$ & $138 \pm 10 \mathrm{c}$ & $21 \pm 5 c$ & $1 \pm 0 c$ \\
\hline C. etunicatum & $436 \pm 11 d$ & $59.6 \pm 9.9 \mathrm{~b}$ & $187.2 \pm 8.9 \mathrm{~b}$ & $1.38 \pm 0.13 \mathrm{a}$ & $6.94 \pm 0.89 \mathrm{~b}$ & $51 \pm 3 b c$ & $150 \pm 12 c$ & $29 \pm 6 c$ & $4 \pm 1 b$ \\
\hline D. versiformis & $552 \pm 21 \mathrm{c}$ & $81.5 \pm 8.0 \mathrm{a}$ & $256.0 \pm 8.2 \mathrm{a}$ & $1.53 \pm 0.26 \mathrm{a}$ & $10.08 \pm 0.68 a$ & $58 \pm 5 a$ & $226 \pm 11 b$ & $65 \pm 7 a$ & $9 \pm 1 \mathrm{a}$ \\
\hline F. mosseae & $761 \pm 27 a$ & $91.6 \pm 8.5 \mathrm{a}$ & $287.6 \pm 7.7 \mathrm{a}$ & $1.25 \pm 0.24 \mathrm{a}$ & $9.24 \pm 0.77 \mathrm{a}$ & $60 \pm 3 a$ & $298 \pm 6 a$ & $61 \pm 5 a$ & $4 \pm 1 b$ \\
\hline R.intraradices & $629 \pm 9 b$ & $84.3 \pm 7.6 \mathrm{a}$ & $264.7 \pm 9.2 \mathrm{a}$ & $1.39 \pm 0.28 \mathrm{a}$ & $9.25 \pm 0.69 \mathrm{a}$ & $56 \pm 3 \mathrm{ab}$ & $206 \pm 13 b$ & $46 \pm 5 b$ & $4 \pm 1 b$ \\
\hline
\end{tabular}

Note: Data (means \pm SD, $\mathrm{n}=4$ ) followed by different letters indicate significant differences $(\mathrm{P}<0.05)$ between treatments

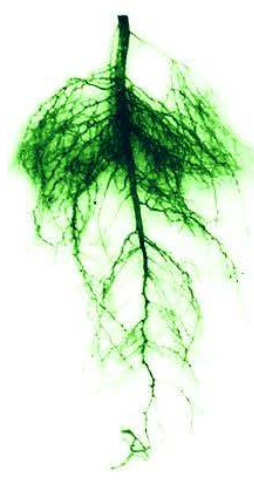

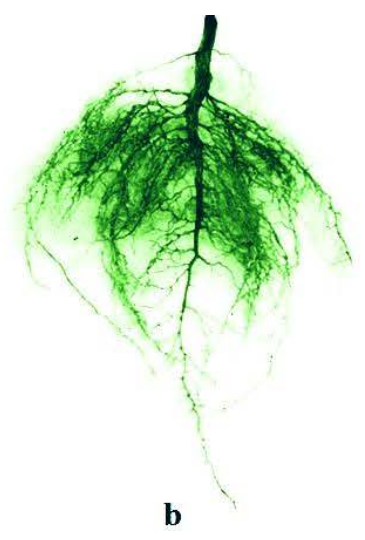

b

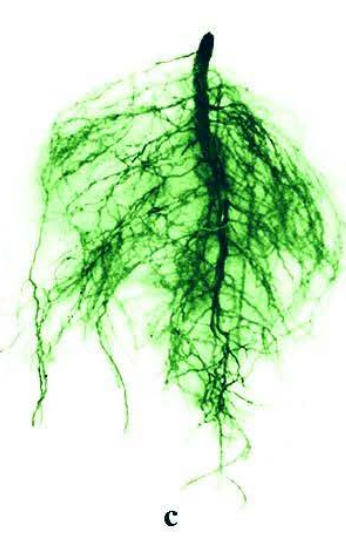

c

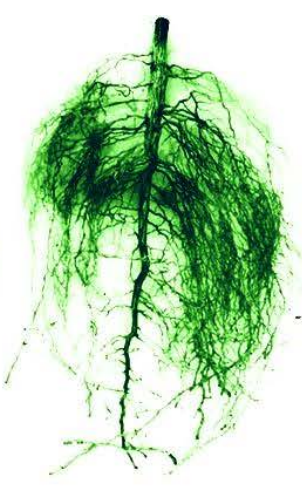

d

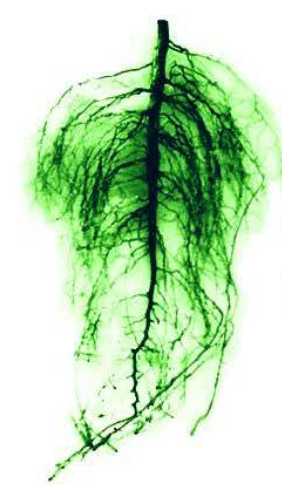

$\mathbf{e}$

Fig. 1. Root morphology of trifoliate orange (Poncirus trifoliata) seedlings treated with a) non-AMF; b) Claroideoglomus etunicatum; c) Diversispora versiformis; d) Funneliformis mosseae; e) Rhizoglomus intraradices

colonized seedlings (Table 2). F. mosseae showed significantly superior response on these root-related traits than other three AMF species. These observations are in agreement with our previous study in trifoliate orange (Wu et al., 2015a).

\section{Response on leaf carbohydrates}

It is a known fact that root growth is strongly dependent on carbon import, and the major loss of root carbon is due to root respiration and AM growth (Walter and Nagel, 2006). AMFseedlings showed significantly lower leaf sucrose concentration, but significantly higher leaf glucose concentration, as compared with non-AMF seedlings (Fig. 2), regardless of AMF species. Such responses were observed highly variable. Maximum reduction in leaf glucose concentration was observed with $D$. versiformis (45.97\%), followed by $F$. mosseae (42.25\%), $R$. intraradices (34.84\%) and C. etunicatum (14.41\%) over uninoculated control. While, mycorrhization induced significantly higher glucose concentration in leaves with $D$. versiformis and $F$. mosseae (30.00-30.70\%) followed by $R$. intraradices (21.44\%) and C. etunicatum (5.22\%) over control. While, the response of AMF on fructose concentration was entirely different. Only $F$. mosseae produced an increase in leaf fructose concentration by $13.45 \%$ over non-AMF control (Fig. 2). AMF as a symbiotic fungi, rely on the host plant to provide carbohydrates for its own growth (Bago et al., 2003), and glucose would be preferentially absorbed and transformed in terms of sucrose cleaving (Schubert et al., 2004) to support the uninterrupted growth. Root mycorrhizal colonization was significantly and positively correlated with leaf glucose and fructose, and negatively with leaf sucrose (Table 3), due to sucrose cleavage (Wu et al., 2015a). AMF-induced root modification was significantly negatively correlated with leaf sucrose but positively with leaf fructose and glucose, indicating that mycorrhiza-induced changes in carbohydrates are associated with changes in root morphology and numbers of LR formation (Table 3). A relatively greater hexose level in AMF plants would provide greater substrates for the growth of both AMF and roots. Glucose stimulates the accumulation of a transcription factor or Auxin-mediated signalling for root initiation (Mishra et al., 2009; Singh et al., 2014). As a result, the AMF-induced root modification is so closely related to the AMF-stimulated sucrose cleavage.

\section{Response on leaf $\mathrm{NO}$ and $\mathrm{CaM}$}

Compared with non-AMF treatment, leaf $\mathrm{NO}$ and $\mathrm{CaM}$ levels were significantly higher with mycorrhization conditions, irrespective of AMF species (Fig. 3). As much as 46.35\%, 74.92\%, $103.14 \%$, and $8.75 \%$ significantly higher leaf $\mathrm{NO}$ concentration was observed upon inoculation with C. etunicatum, $D$. versiformis, $F$. mosseae, and $R$ intraradices, respectively, over non-AMFseedlings. Likewise $28.65 \%, 35.15 \%, 27.94 \%$ and $15.01 \%$ significantly higher leaf $\mathrm{CaM}$ concentration was observed in $C$. etunicatum, D. versiformis, $F$. mosseae, and $R$ intraradices, respectively, over non-AMF-seedlings. These results are in agreement with the results of Huang et al. (2014) in trifoliate orange. Strong correlation of $\mathrm{NO}$ and $\mathrm{CaM}$ with root AMF colonization suggested that, root AMF colonization could be driven through $\mathrm{NO}$ and $\mathrm{CaM}$ (Huang et al., 2014). Leaf $\mathrm{NO}$ and $\mathrm{CaM}$ also correlated positively with root total length and number of LR in first order, indicating that AMF-induced $\mathrm{NO}$ and $\mathrm{CaM}$ as a signalling molecule are partly involved in the root development. Both $\mathrm{NO}$ and CaM interacted synergistically to stimulate root development and LR formation with the cross-talk of auxins (Liao et al., 2012). The interaction between NO and $\mathrm{CaM} / \mathrm{Ca}^{2+}$ under mycorrhizaiton would further decode the underlying mechanisms involved. 
20

Table 3. Correlation coefficients between root colonization, root morphological traits, or lateral root (LR) number and physiological variables in trifoliate orange (Poncirus trifoliata) seedlings colonized by Claroideoglomus etunicatum, Diversispora versiformis, Funneliformis mosseae, and Rhizoglomus intraradices $(n=20)$

\begin{tabular}{|c|c|c|c|c|c|c|c|c|c|c|}
\hline & \multirow[b]{2}{*}{$\begin{array}{l}\text { Root AMF } \\
\text { colonization }\end{array}$} & \multirow{2}{*}{$\begin{array}{c}\text { Total } \\
\text { root } \\
\text { length }\end{array}$} & \multirow{2}{*}{$\begin{array}{c}\text { Root } \\
\text { project } \\
\text { area }\end{array}$} & \multirow{2}{*}{$\begin{array}{c}\text { Root } \\
\text { surface } \\
\text { area } \\
\end{array}$} & \multirow[b]{2}{*}{$\begin{array}{c}\text { Root } \\
\text { diameter }\end{array}$} & \multirow[b]{2}{*}{$\begin{array}{c}\text { Root } \\
\text { volume }\end{array}$} & \multicolumn{4}{|c|}{ LR number } \\
\hline & & & & & & & $\begin{array}{l}\text { First- } \\
\text { order }\end{array}$ & $\begin{array}{l}\text { Second- } \\
\text { order }\end{array}$ & $\begin{array}{l}\text { Third- } \\
\text { order }\end{array}$ & $\begin{array}{l}\text { Forth- } \\
\text { order }\end{array}$ \\
\hline Sucrose & $-0.86^{* *}$ & $-0.90^{* *}$ & $-0.80^{* *}$ & $-0.92^{* *}$ & 0.24 & $-0.73^{* *}$ & $-0.73^{* *}$ & $-0.78^{* *}$ & $-0.93^{* *}$ & $-0.67^{* *}$ \\
\hline Fructose & $0.68^{* *}$ & $0.65^{* *}$ & $0.48^{*}$ & $0.59^{* *}$ & -0.30 & 0.34 & 0.42 & $0.64^{* *}$ & $0.61^{* *}$ & 0.36 \\
\hline Glucose & $0.81^{* *}$ & $0.93^{* *}$ & $0.79^{* *}$ & $0.94^{* *}$ & -0.18 & $0.76^{* *}$ & $0.72^{* *}$ & $0.85^{* *}$ & $0.93^{* *}$ & $0.61^{* *}$ \\
\hline $\mathrm{NO}$ & $0.74^{* *}$ & $0.63^{* *}$ & 0.41 & $0.54^{* *}$ & -0.31 & 0.32 & $0.62^{* *}$ & $0.75^{* *}$ & 0.39 & -0.16 \\
\hline $\mathrm{CaM}$ & $0.79^{* *}$ & $0.45^{*}$ & 0.32 & 0.43 & -0.27 & 0.29 & $0.46^{*}$ & 0.44 & 0.28 & 0.07 \\
\hline
\end{tabular}

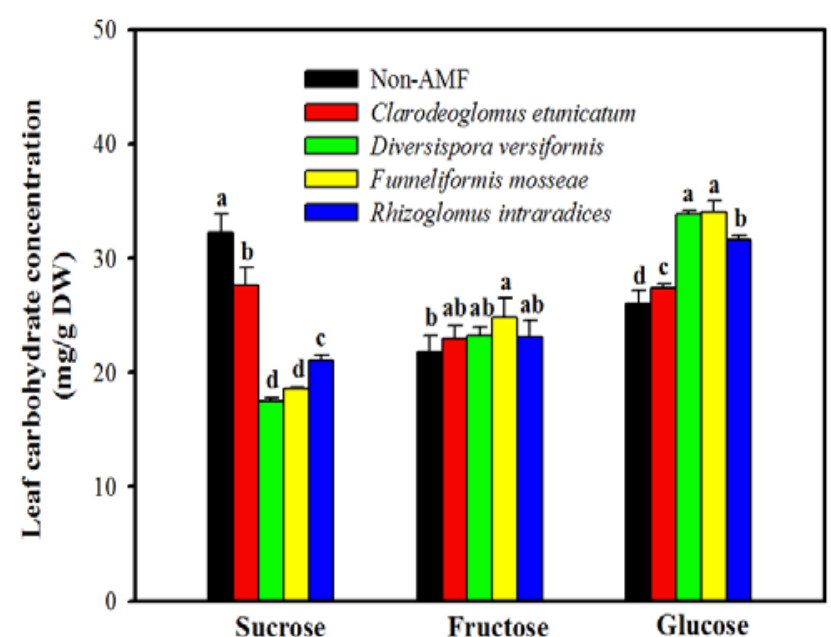

Fig. 2. Leaf sucrose, fructose, and glucose concentrations in trifoliate orange (Poncirus trifoliata) seedlings colonized by Claroideoglomus etunicatum, Diversispora versiformis, Funneliformis mosseae, and Rhizoglomus intraradices. Data (means $\pm \mathrm{SD}, n=4$ ) followed by different letters above bars indicate significant differences $(P<0.05)$ between treatments

\section{Correlation studies}

Different root traits display a significant correlation with three forms of carbohydrate, NO and CaM in leaves (Table 3). Amongst LR numbers, first-order, second-order, third-order, and fourth-order were negatively correlated with leaf sucrose concentration $(r=-0.67 \sim-0.93, P<0.01)$ and positively correlated with leaf glucose concentration $(r=0.61 \sim 0.93, P<$ $0.01)$, corresponding to pattern of similar response on root volume viz., root volume versus sucrose $(r=-0.73, P<0.01)$ and root volume cooperate with leaf glucose concentration $(r=$ $0.76, P<0.01)$. The other root related parameters like root AMF-colonization, total root length, root projected area, and root surface area were positively correlated with fructose as well as glucose concentration in leaves. With exception of root projected area, leaf $\mathrm{NO}$ and $\mathrm{CaM}$ concentration showed a positive correlation with root AMF-colonization $(r=0.74$ and $0.79, P<0.01)$ and total root length $(r=0.63$ and $0.45, P<$ 0.01 and $P<0.05$, respectively), and with root diameter remaining unaffected with any of the three forms of carbohydrates, NO, and CaM in leaves. These observations suggested, mycorrhizal response of trifoliate orange is strongly dependent upon leaf carbohydrate metabolism, NO, and CaM activity, as underlying mechanisms to explain the physiological responses of AMF.

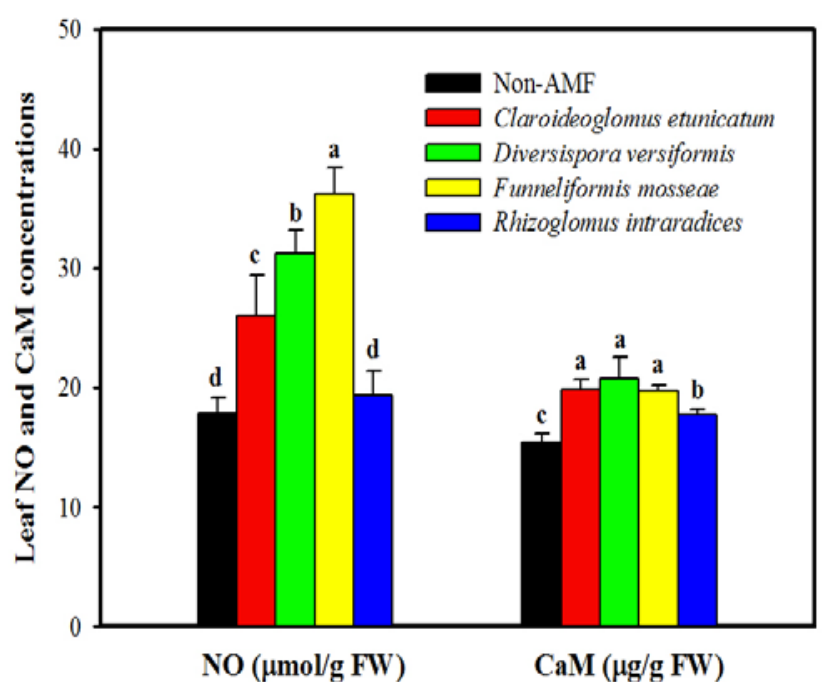

Fig. 3. Concentrations of leaf $\mathrm{NO}$ and $\mathrm{CaM}$ in trifoliate orange (Poncirus trifoliata) seedlings colonized by Claroideoglomus etunicatum, Diversispora versiformis, Funneliformis mosseae, and Rhizoglomus intraradices. Data (means $\pm \mathrm{SD}, n=4$ ) followed by different letters above the bars indicate significant differences $(P<0.05)$ between treatments

\section{Conclusions}

Responses of trifoliate orange to mycorrhization are regulated through carbon metabolism coupled with root morphological changes. These changes were further partitioned, partly into sucrose cleavage and partly as NO- and CaM-induced changes.

\section{Acknowledgements}

This study was supported by the Plan in Scientific and Technological Innovation Team of Outstanding Young, Hubei Provincial Department of Education, China (T201604).

\section{References}

Aguín O, Mansilla JP, Vilariõo A, Sainz MJ (2004). Effects of mycorrhizal inoculation on root morphology and nursery production of three grapevine rootstocks. American Journal of Ecology and Viticulture 55:108-111. 
Bago B, Pfeffer PE, Abubaker J (2003). Carbon export from arbuscular mycorrhizal roots involves the translocation of carbohydrate as well as lipid. Plant Physiology 131:496-507.

Borowicz VA (2010). The impact of arbuscular mycorrhizal fungi on strawberry tolerance to root damage and drought stress. Pedobiologia 53:265-270.

Chen YH, Kao CH (2012). Calcium is involved in nitric oxide- and auxininduced lateral root formation in rice. Protoplasma 249:187-195.

Fusconi A (2014). Regulation of root morphogenesis in arbuscular mycorrhizae: What role do fungal exudates, phosphate, sugars and hormones play in lateral root formation? Annals of Botany 113:19-33.

Gutjahr C, Casieri L, Paszkowski U (2009). Glomus intraradices induces changes in root system architecture of rice independently of common symbiosis signaling New Phytologist 182:829-837.

Huang YM, Srivastava AK, Zou YN, Ni QD, Han Y, Wu QS (2014). Mycorrhizal-induced calmodulin mediated changes in antioxidant enzymes and growth response of drought-stressed trifoliate orange. Frontiers in Microbiology 5:682.

Isobe K, Murakami S, Tateishi A, Nomura K, Inoue H, Tsuboki Y (2002). Effects of arbuscular mycorrhizal fungi on the morphology of kidney bean root.Japanese Journal of Crop Science 71:91-95.

Jung JKH, McCouch S (2013). Getting to the root so fit: genetic and hormonal control of root architecture. Frontiersin Plant Science 4:186.

Kiers ET, van der Heijden M (2006). Mutualistic stability in the arbuscular mycorrhizal symbiosis: exploring hypotheses of evolutionary cooperation. Ecology 87: 1627-1636.

Li Y,Zou YN, Wu QS (2013). Effects of Diversispora spurca inoculation on growth, root system architecture and chlorophyll contents of four citrus genotypes. International Journal of Agriculture and Biology 15:342-346.

Liao BW, Zhang ML, Huang GB, Yu JH (2012). $\mathrm{Ca}^{2+}$ and $\mathrm{CaM}$ are involved in NO- and $\mathrm{H}_{2} \mathrm{O}_{2}$-induced adventitious root development in Marigold.Journal of Plant Growth Regulation 31:253-264.

Mishra BS, Singh M, Aggrawal P, Laxmi A (2009). Glucose and auxin signaling interaction in controlling Arabidopsis thaliana seedlings root growth and development. PLoSONE4:e4502.

Ortas I, Sari N, Akpinar C, Yetisir H (2011). Screening mycorrhiza species for plant growth, $\mathrm{P}$ and $\mathrm{Zn}$ uptake in pepper seedlings grown under greenhouse conditions. Scientia Horticulturae 128:92-98.

Parniske M (2008). Arbuscular mycorrhiza: the mother of plant root endosymbioses. Nature Reviews Microbiology 6:763-775.

Phillips JM, Hayman DS (1970). Improved procedures for clearing roots and staining parasitic and vesicular-arbuscular mycorrhizal fungi for rapid assessment of infection. Transactions of the British Mycological Society 55:158-161.

Schellenbaum L, Berta G, Ravolanirina F, Tisserant B, Gianinazzi S, Fitter $\mathrm{AH}$ (1991). Influence of endomycorrhizal infection on root morphology in a micropropagated woody plant species (Vitisvinifera L.). Annals of Botany 68:135-141.

Schubert A, Allara P, Morte A (2004). Cleavage of sucrose in roots of soybean (Glycine max) colonized by an arbuscular mycorrhizal fungus. New Phytologist 161:495-501.
Singh M, Gupta A, Laxmi A (2014). Glucose control of root growth direction in Arabidopsis thaliana. Journal of Experimental Botany 65:113.

Smith SE, Read DJ (2008). Mycorrhizal symbiosis. New York, NY, USA Academic Press

Sorgona A, Abenavoli M, Gringeri P, Lupini A, Cacco G (2007). Root architecture plasticity of citrus rootstocks in response to nitrate availability.Journal of Plant Nutrient 30:1921-1932.

Srivastava AK, Singh S (2009). Citrus dedine: Soil fertility and plant nutrition.Journal of Plant Nutrition 32:197-245.

Srivastava AK, Singh S, Albrigo LG (2008). Diagnosis and remediation of nutrient constraints in Citrus. Horticultural Reviews 34:277-364.

Walter A, Nagel KA (2006). Root growth reacts rapidly and more pronounced than shoot growth towards increasing light intensity in tobacco seedlings. Plant Signal Behavior 1:225-226.

Wu QS, Cao MQ, Zou YN, Wu C, He XH (2016). Mycorrhizal colonization represents functional equilibrium on root morphology and carbon distribution of trifoliate orange grown in a split-root system. ScientiaHorticulturae 199:95-102.

Wu QS, Lou YG, Li Y (2015a). Plant growth and tissue sucrose metabolism in the system of trifoliate orange and arbuscular mycorrhizal fungi. Scientia Horticulturae 181:189-193.

Wu QS, Srivastava AK, Li Y (2015b). Effects of mycorrhizal symbiosis on growth behavior and carbohydrate metabolism of trifoliate orange under different substrate P levels. Journal Plant Growth Regulation 34:499-508.

Wu QS,Zou YN, HeXH,Luo P (2011). Arbuscular mycorrhizal fungican alter some root characters and physiological status in trifoliate orange (Poncirus trifoliata L. Raf.) seedlings. Plant Growth Regulation 65:273278.

Wu QS, Zou YN, Zhan TT, Liu CY (2010). Polyamines participate in mycorrhizal and root development of citrus (Citrus tangerine) seedlings. Notulae Botanicae Horti Agrobotanici Cluj-Napoca38:25-31.

Yang L, Ji W, Zhu Y, Gao P, Li Y, Cai H, Bai X, Guo DJ (2010). GsCBRLK, a calcium/calmodulin-binding receptor-like kinase, is a positive regulator of plant tolerance to salt and ABA stress. Journal of Experimental Botany 61:2519-2533.

Yao Q, Wang LR, Zhu HH, Chen JZ (2009). Effect of arbuscular mycorrhizal fungal inoculation on root system architecture of trifoliate orange (Poncirus trifoliata L. Raf.) seedlings. Scientia Horticculturae 121:458-461.

Zhao DY, Tian QY, Li YH, Zhang WH (2007). Nitric oxide is involved in nitrate-induced inhibition of root elongation in Zea mays. Annals of Botany 100:497-503.

Zhang RQ, Zhu HH, Zhao HQ, Yao Q (2013). Arbuscular mycorrhizal fungal inoculation increases phenolic synthesis in clover roots via hydrogen peroxide, salicylic acid and nitric oxide signaling pathways. Journal of Plant Physiology 170:7479. 